\title{
PERANAN EKSPLORASI PUSTAKA UNTUK MENINGKATKAN KETERAMPILAN MENULIS PADA SISWA KELAS IV SD NEGERI 200212 PADANGSIDIMPUAN TAHUN PELAJARAN 2014/2015
}

\author{
JAMILAH SIKUMBANG, S.Pd. SD. \\ NIP: 196503231986042006.
}

Email : jamilahsikumbang2@gmail.com

\begin{abstract}
abstrak
Penelitian ini merupakan hasil penelitian tindakan kelas (PTK) di SDN 200212 Padangsidimpuan, pada kelas IV (Semester 2) tahun ajaran 2014/2015. Kesulitan pembelajaran berawal dari permasalahan "Bagaimana meningkatkan ketrampilan menulis pada siswa kelas IV di SDN 200212 Padangsidimpuan?".

Dalam Kerangka Berpikir memuat latar belakang dan rumusan masalah, kemudian menetapkan Hipotesis. Hipotesis yang pertama adalah dengan hanya menggunakan strategi pembelajaran pada umumnya (konvensional) misalnya pemberian tugas, siswa kurang dapat termotivasi untuk meningkatkan ketrampilan menulis. Dan hipotesis yang kedua adalah dengan adanya penerapan eksplorasi pustaka sebagai metode pembelajaran membaca dan menulis mempunyai pengaruh positif dan signifikan terhadap peningkatan ketrampilan menulis siswa.

Disini Penelitian melalui 2 siklus, dengan tujuan ada perubahan peningkatan terjadi pada tiap siklusnya. Pada siklus I (masih bersifat konvensional) ada sedikit peningkatan, namun belum menunjukkan hasil yang maksimal karena masih ada siswa yang belum mencapai batas ketuntasan minimal. Kemudian dilanjutkan pada siklus II (dengan menggunakan peranan eksplorasi pustaka) dan hasilnya menunjukkan peningkatan dalam jumlah nilai pada kategori A, B dam C. Sedangkan pada kategori D dan C menunjukkan penurunan jumlah siswa. Untuk itu PTK (Penelitian Tindakan Kelas) dihentikan pada siklus ke II.

Profesionalitas guru untuk melakukan pembelajaran secara aktif, kreatif, efektif, inovatif dan menyenangkan sangat dibutuhkan dalam pelaksanaan KBM (Kegiatan Belajar Mengajar). Sehingga kendala-kendala dapat teratasi dengan baik, dan prestasi belajar siswa dapat meningkat.
\end{abstract}

\section{PENDAHULUAN}

Bahasa Indonesia sebagai Bahasa Negara menjadi bahasa pengantar dalam pendidikan nasional. Hal ini dapat diartikan bahwa Bahasa Indonesia mcrupakan bahasa pengantar di semua jenjang pendidikan, mulai dari pendidikan anak usia dini yang berbentuk Taman Kanak - Kanak, Raudatul Athfal ( RA ) atau bentuk lain yang sederajat sampai dengan Perguruan Tinggi, memiliki peran yang sangat penting juga kehidupan anak sehari-hari dalam keluarga, Bahasa Indonesia sudah menjadi bahasa ibu. Karena kemampuan orang tua dalam menggunakan bahasa ibu ( Bahasa Jawa ) kurang dipahami oleh orang tua.
Sehingga peran bahasa Indonesia sangat penting dan dominant. Lahirnya UU No. 20 Tahun 2003 tentang Sistem Pendidikan Nasional telah membawa dampak bagi pembelajaran Bahasa Indonesia.Seseorang yang selalu membaca diwaktu luang adalah ciri orang yang minat bacanya tinggi. Dengan membaca, anak akan merasa betapa banyak fenomena alam maupun lingkungan sosial yang belum mereka ketahui.(genta,1998).

Begitu juga dengan menulis, adalah merupakan kegiatan yang mudah, hanya membutuhkan pensil dan secarik kertas. Namun tulisan yang baik memerlukan ketrampilan dan kebiasaan yang terasah dari bakat yang ada pada diri sendiri.(genta,1998) 
Berbagai cara yang pernah dilaksanakan oleh guru dalam upaya meningkatkan kemampuan berbahasa pada siswa tidaklah sedikit. Antara lain memberi tugas di rumah (PR) dalam bentuk portofolio maupun bentuk tugas proyek lainnya. Namun hal itu ternyata masih kurang dapat meningkatkan bakat maupun minat pada siswa didik untuk gemar membaca dan menulis.

$$
\begin{array}{ccc}
\text { Pada Kurikulum } & \text { Berbasis Kompetensi, } \\
\text { awal dimulainya kurikulum yang }
\end{array}
$$
menitikberatkan pada peningkatan dan pengembangan terhadap kemampuan bakat siswa, setiap individu dalam diri siswa pasti ada kelebihan, yang mana hal tersebut merupakan bakat yang harus diasah, sehingga bakat tersebut menjadi sesuatu yang menjadi nilai lebih dalam diri siswa. Karena pembelajaran belumlah maksimal apabila siswa belum dapat berkembang kemampuan bakat dan kreativitasnya.

Ketrampilan menulis siswa berkaitan erat dengan kegiatan membaca. Faktor yang mampu mendorong Minat Baca antara lain : 1) Rasa ingin tahu atas fakta, teori, prinsip, pengetahuan, informasi dan lainnya. 2) Fasilitas yang memadai. 3) Terciptanya situasi yang kondusif . 4) Membaca adalah suatu kebutuhan.

Perhatian dan kegiatan pembelajaran Bahasa Indonesia dikembangkan menjadi Ketrampilan berbahasa, bukan lagi pengajaran tentang tata bahasa. Keterampilan berbahasa yang dimaksud meliputi mendengar, berbicara, membaca dan menulis yang dijabarkan secara terpadu.

Sesuai dengan Keputusan Menteri Pendidikan dan Kebudayaan No. 0601U/1993 tanggal 25 Pebruari 1993. Tentang Kurikulum Pendidikan Dasar. Dalam Kurikulum tersebut salah satu mata pelajaran yang diajarkan di SD ialah Bahasa Indonesia. Bahasa Indonesia sebagaimana fungsi bahasa adalah merupakan salah satu alat komunikasi. Melalui Bahasa Manusia dapat saling berhubungan (berkomunikasi), saling berbagi pengalaman, saling belajar dari yang lain, dan meningkatkan kemampuan intelektual. Mata Pelajaran Bahasa Indonesia adalah program untuk mengembangkan pengetahuan keterampilan berbahasa, dan sikap positif terhadap Bahasa Indonesia.
Mata Pelajaran Bahasa Indonesia tersebut di Sekolah Dasar telah diuraikan dalam Garis Garis Besar Program Pengajaran ( GBPP ) kurikulum Sekolah Dasar Kelas II. Untuk memahami dan melaksanakannya perlu dipelajari dan dianalisa dengan tujuan untuk memberikan arahan kepada guru dalam melaksanakan kegiatan belajar mengajar khususnya belajar mengajar mata pelajaran Bahasa Indonesia kelas II Sekolah Dasar.

Di atas telah disebutkan bahwa hakekatnya belajar bahasa adalah belajar komunikasi. Oleh karena itu pembelajaran Bahasa Indonesia diarahkan untuk meningkatkan kemampuan siswa dalam berkomunikasi dengan Bahasa Indonesia baik secara lisan maupun tertulis.

Proses belajar mengajar dilaksanakan melalui komunikasi timbal balik dan tidak semata-mata merupakan pemberian informasi searah tanpa mengembangkan gagasan, kreatifitas dan nilai serta keterampilan baik secara mandiri maupun dalam suasana kebersamaan. Siswa diaktifkan dalam belajar agar mampu mengembangkan, baik berupa pengetahuan sikap dan nilai maupun keterampilan serta mampu menerapkan Proses Belajar Mengajar yang menganut cara belajar siswa aktif, berorientasi kepada siswa itu sendiri. Hal ini memungkinkan siswa itu berfikir, bersikap dan bertindak kreatif sehingga dikemudian hari mereka dapat menghadapi perubahan - perubahan masyarakat dan memberikan sumbangan bagi pembangunan Bangsa.

Sebagai salah satu pedoman pelaksanaan kurikulum, pedoman penggunaan sarana dalam kegiatan dalam kegiatan belajar mengajar memberikan acuan yang menyangkut penggunaan sarana dalam melaksanakan program dan pengembangan kurikulum. Serta garis-garis besar Program Pengajaran. Dengan demikian, pedoman ini merupakan bagian tak terpisahkan dari peringkat kurikulum. Pedoman penggunaan sarana dalam kegiatan belajar mengajar ini digunakan pada jenjang pendidikan dasar tetapi 
tidak menutup kemungkinan untuk jenjang pembelajaran di kelas. Penelitian ini juga pendidikan yang lebih tinggi dengan sumber termasuk penelitian deskriptif, sebab gagasan bagi para pelaksana pembina lapangan menggambarkan bagaimana suatu teknik karena ini pedoman penggunaan sarana dalam pembelajaran diterapkan dan bagaimana hasil kegiatan belajar mengajar di sekolah Dasar perlu yang diinginkan dapat dicapai.

disempurnakan sesuai dengan penggunaannya pada jenjang Sekolah Dasar.

Menurut Sukidin dkk. (2002:54) ada 4

Dalam proses belajar mengajar yang penelitian tindakan guru sebagai peneliti, (2) menjadi masukan utama adalah materi pelajaran, penelitian tindakan kolaboratif, (3) penelitian metode, tujuan, sarana belajar mengajar dan tindakan simultan terintegratif, dan (4) penelitian penilaian. Dengan demikian sarana yang meliputi tindakan sosial eksperimental.

buku, alat pelajaran, media ( Pandang / video, dengan radio dan lain-lain ), perabot sekolah dengan bangunan sekolah ruang belajar, merupakan satu unsur dalam kegiatan belajar mengajar. Ini bertujuan memberi pedoman bagaimana merencanakan penggunaan sarana kegiatan belajar mengajar atau tujuan instruksional dapat tercapai secara optimal.

Dalam mengatasi permasalahan ini, penulis ingin memberikan masukan tentang Eksplorasi Pustaka sebagai wadah pengembangan bidang kebahasaan dan kesastraan. Dengan menggunakan fasilitas perpustakaan yang ada di sekolah, siswa dapat memanfaatkan perpustakaan sebagai sumber belajar, dengan begitu siswa telah melakukan pembelajaran eksplorasi terhadap lingkungannya.

Keempat bentuk penelitian tindakan di atas, ada persamaan dan perbedaannya. Menurut Oja dan Smulyan sebagaimana dikutip oleh Kasbolah, (dalam Sukidin, dkk. 2002:55), ciriciri dari setiap penelitian tergantung pada:(1) tujuan utamanya atau pada tekanannya, (2) tingkat kolaborasi antara pelaku peneliti dan peneliti dari luar, (3) proses yang digunakan dalam melakukan penelitian, dan (4) hubungan antara proyek dengan sekolah.

Dalam penelitian ini menggunakan bentuk guru sebagai peneliti, dimana guru sangat berperan sekali dalam proses penelitian tindakan kelas. Dalam bentuk ini, tujuan utama penelitian tindakan Kelas IValah untuk meningkatkan praktik-praktik pembelajaran di kelas. Dalam kegiatan ini, guru terlibat langsung secara penuh dalam proses perencanaan, tindakan, observasi,

Mengapa Eksplorasi Pustaka menjadi pilihan? Pertanyaan tersebut muncul ketika guru mengalami kendala dalam menyampaikan pembelajaran mengarang(menulis cerita) maupun menulis sinopsis yang sering menjadi bahan untuk lomba. Melihat hasil penulisan siswa dalam bercerita atau membuat sinopsis, sangat banyak siswa yang menulis asal jadi saja, padahal kita sebagai guru telah menyampaikan cara-cara menulis sebuah cerita dengan harapan siswa bisa menulis dengan lebih baik.

\section{METODE PENELITIAN}

dan refleksi. Kehadiran pihak lain dalam penelitian ini peranannya tidak dominan dan sangat kecil.

Penelitian ini mengacu pada perbaikan pembelajaran yang berkesinambungan. Kemmis dan Taggart (1988:14) menyatakan bahwa model penelitian tindakan adalah berbentuk spiral. Tahapan penelitian tindakan pada suatu siklus meliputi perencanaan atau pelaksanaan observasi dan refleksi. Siklus ini berlanjut dan akan dihentikan jika sesuai dengan kebutuhan dan dirasa sudah cukup.

Penelitian ini merupakan penelitian tindakan (action research), karena penelitian dilakukan untuk memecahkan masalah 


\section{HASIL PENELITIAN DAN PEMBAHASAN}

\section{A. HASIL PENELITIAN}

1. Temuan Hasil Pengamatan

Tabel 4.2 Hasil Nilai Siklus I

\begin{tabular}{|c|c|}
\hline NILAI & $\begin{array}{c}\text { JUMLAH } \\
\text { SISWA }\end{array}$ \\
\hline $\mathrm{A}=9.0-10$ & 0 \\
\hline $\mathrm{B}=8.0-8.9$ & 1 \\
\hline $\mathrm{C}=7.0-7.9$ & 12 \\
\hline $\mathrm{D}=6.0-6.9$ & 12 \\
\hline $\mathrm{E}<6.0$ & 1 \\
\hline $\begin{array}{l}\text { TOTAL } \\
\text { SISWA }\end{array}$ & 26 \\
\hline
\end{tabular}

Tabel 4. 4 Hasil Nilai Siklus II

\begin{tabular}{|c|c|}
\hline NILAI & $\begin{array}{c}\text { JUMLAH } \\
\text { SISWA }\end{array}$ \\
\hline $\mathrm{A}=9.0-10$ & 1 \\
\hline $\mathrm{B}=8.0-8.9$ & 9 \\
\hline $\mathrm{C}=7.0-7.9$ & 15 \\
\hline $\mathrm{D}=6.0-6.9$ & 1 \\
\hline $\mathrm{E}<6.0$ & 0 \\
\hline TOTAL & 26 \\
SISWA & \\
\hline
\end{tabular}

Tabel 4.5 PROSENTASE

\section{PENCAPAIAN TARGET}

\begin{tabular}{|c|c|c|c|c|c|c|}
\hline N & K & \multicolumn{2}{|c|}{ SIKLUS I } & \multicolumn{2}{c|}{ SIKLUS } & KETERANGAN \\
O & A & \multicolumn{2}{|c|}{} & \\
& T & \multicolumn{2}{|c|}{} & \\
& E & \multicolumn{2}{|c|}{} & & \\
\hline & & & & & & \\
\hline 1 & A & 0 & $0 \%$ & 1 & $4 \%$ & Meningkat \\
\hline 2 & B & 1 & $4 \%$ & 9 & $39 \%$ & Meningkat \\
\hline 3 & C & 12 & $42 \%$ & 15 & 53 & Meningkat \\
\hline 4 & D & 12 & $50 \%$ & 1 & $4 \%$ & Menurun \\
\hline 5 & E & 1 & $4 \%$ & 0 & $0 \%$ & Menurun \\
\hline
\end{tabular}

Diskripsi hasil prosentase :

- Kategori A mengalami kenaikan jumlah siswa sebanyak 1 orang dan mengalami kenaikan prosentasi sebesar $4 \%$.

- Kategori B mengalami kenaikan jumlah siswa sebanyak 10 orang dan mengalami kenaikan prosentasi sebesar $35 \%$.

- Kategori C mengalami kenaikan jumlah siswa sebanyak 3 orang dan mengalami kenaikan prosentasi sebesar $10 \%$.

- Kategori D mengalami penurunan jumlah siswa sebanyak 13 orang dan mengalami penurunan prosentasi sebesar $46 \%$.

- Kategori E mengalami penurunan jumlah siswa sebanyak 4 orang dan mengalami penurunan prosentasi sebesar $4 \%$.

Dari data diatas, tampak perkembangan nilai hasil belajar pada kategori A,B,C, meningkat jadi eksplorasi perpustakaan memberikan pengaruh positif dalam peningkatan hasil belajar. Juga pada kategori D dan E, terjadi penurunan jumlah siswa, yang berarti terjadi peningkatan hasil belajar dari kategori $\mathrm{D}$ dan $\mathrm{E}$ meningkat menjadi kategori A,B atau C.

Kemudian data tersebut disajikan ke dalam bentuk grafik peningkatan pembelajaran antara siklus I dan II. Grafik tersebut akan membantu kita untuk lebih mudah melihat hasil perkembangan peningkatan hasil belajar siswa.

Deskripsi Temuan

Pada Siklus I, hasil pembelajaran kurang memuaskan karena masih banyak siswa yang memiliki nilai rata-rata 6,0 6,9 , antara lain disebabkan:

a. Anak hanya terpaku pada bacaan cerita yang ada pada bacaan buku pelajaran (tidak ada alternatif pilihan yang lain yang menjadi kesukaan anak).

b. Anak kurang tertarik karena ceritanya membosankan (tidak 
ditunjang dengan gambar yang menarik)

c. Metode pembelajaran yang berupa pemberian tugas dari guru, kurang begitu menantang, karena dalam pemberian tugas, anak hanya terdoktrin harus mengerjakan tugas tersebut tanpa dapat menyalurkan semua kemampuan bakat dan minatnya dalam membaca dan menulis cerita sederhana.

Namun setelah diadakan Siklus II, dengan memakai kegiatan eksplorasi pustaka, siswa mengalami perubahan peningkatan, terbukti pada kenaikan jumlah siswa yang mendapat nilai ratarata $9,0-9,9 ; 8,0-8,9 ; \quad 7,0-7,9$ dan penurunan jumlah siswa yang mempunyai nilai rata-rata $6,0-6,9$ dan kurang dari 6,0.

\section{B. PEMBAHASAN HASIL PENELITIAN}

Kegiatan eksplorasi pustaka sangat membantu siswa untuk terjun langsung dengan lingkungannya. Hal-hal yang dapat langsung diperoleh antara lain:

a. Pengalaman tak terlupakan ketika siswa menemukan cerita lalu memahami isi bacaan yang disukainya.

b. Siswa dengan leluasa menikmati bacaan dengan suasana tenang dan santai

c. Siswa dapat menemukan nara sumber lain bila menemukan kesulitan, ini menunjukkan bahwa siswa memiliki rasa ingin tahu yang besar.

Dari beberapa kegiatan yang telah dilakukan oleh guru, ternyata kegiatan pembelajaran dengan metode eksplorasi sangat banyak manfaatnya, baik dilihat dari segi guru maupun siswa.

Dari segi guru, kegiatan eksplorasi pustaka merupakan ide kreatif dan inovatif dalam merencanakan pelaksanaan pembelajaran. Guru hanya berperan sebagai fasilitator dan siswalah yang aktif melakukan kegiatan.
Dari segi siswa, kegiatan eksplorasi pustaka banyak membantu siswa mempelajari karya fiksi maupun non fiiksi, guna mengembangkan dan meningkatkan minat membaca dan menulis. Selain itu suasana kelas tampak lebih aktif karena siswa lebih responsif. Selain itu siswa akan mendapat pengalaman secara langsung dan tidak terlupakan. Minat dan bakat siswa dapat tergali melalui kegiatan eksplorasi yang secara tidak langsung merangsang siswa untuk mempunyai rasa ingin tahu yang besar. Sehingga akan tampak perubahan perkembangan yang sangat mencolok pada diri siswa.

\section{KESIMPULAN}

Kegiatan Pembelajaran yang dilakukan guru bilamana belum mencapai batas ketuntasan menuntut guru untuk melakukan perbaikan pembelajaran. Hal ini dapat dipastikan ketidakberhasilan tersebut karena kurang optimalnya guru melibatkan instrumen pembelajaran dan kurangnya inovasi dan kreativitas dalam menciptakan suasana pembelajaran yang lebih menyenangkan dan memberi pengalaman baru kepada siswa.

Secara umum dapat ditarik kesimpulan sebagai berikut :

1. Keberhasilan siswa dapat ditingkatkan karena guru dapat merancang strategi pembelajarannya secara tepat.

2. Keaktifan siswa dalam mengikuti pelajaran meningkat karena guru memilih dan menciptakan metode secara kreatif dan inovatif sehingga tidak membosankan.

3. Kemampuan, kreativitas dan profesionalitas guru teruji setelah melakukan kegiatan perbaikan pembelajaran dengan hasil yang memuaskan.

4. Kegiatan Eksplorasi pustaka dapat menumbuhkan minat pada siswa dalam membaca dan menulis.

5. Kegiatan pembelajaran yang menyenangkan dapat tercipta. 
Volume 3 Nomor 1, Halaman 1-81, Januari--Juni 2018

RISTEKDIK | Jurnal Bimbingan dan Konseling

P-ISSN: 2527-4244, E-ISSN : 2541-206X

\section{DAFTAR PUSTAKA}

Suparno. 2003. Ketrampilan Dasar Menulis. Jakarta : Universitas Terbuka

Wardani I.G.A.K. 2003. Penelitian Tindakan Kelas. Jakarta : Universitas Terbuka

Andayani Dkk. 2015. Pemantapan Kemampuan Profesional (Panduan). Jakarta : Universitas Terbuka

Suprayekti Dkk. 2005. Pembaharuan Pembelajaran di SD. Jakarta : Universtas Terbuka

Joan Beck. 2003. Meningkatkan Kecerdasan Anak, hal 154-155. Jakarta : Delapratasa 